\title{
Complications according to underlying disease in children undergoing video-assisted gastrostomy
}

\author{
Authors: \\ Margrét Brands Viktorsdóttir MD ${ }^{1}$ \\ Martin Salö, $\mathrm{MD}, \mathrm{PhD}^{2}$ \\ Pernilla Stenström, $\mathrm{MD}, \mathrm{PhD}^{3}$ \\ Magnus Anderberg, MD, $\mathrm{PhD}^{4}$ \\ Anna Börjesson, $\mathrm{MD}, \mathrm{PhD}^{5}$ \\ Einar Arnbjörnsson, MD, Professor ${ }^{6}$ \\ Torbjörn Backman, $\mathrm{MD}, \mathrm{PhD}^{7}$ \\ Authors' e-mails: \\ ${ }^{1}$ margret.viktorsdottir@skane.se \\ 2 martin.salo@med.lu.se \\ 3 pernilla.stenstrom@med.lu.se \\ ${ }^{4}$ magnus.anderberg@med.lu.se \\ 5 anna.borjesson@skane.se \\ ${ }^{6}$ einar.arnbjornsson@telia.com \\ ${ }^{7}$ torbjorn.backman@skane.se
}

\begin{abstract}
Affiliations:
Department of Pediatric Surgery, Skåne University Hospital and the Department of Clinical Sciences, Pediatrics, Lund University, Lund, Sweden
\end{abstract}

\section{Corresponding author:}

Einar Arnbjörnsson, $\mathrm{MD}, \mathrm{PhD}$, Professor, Department of Pediatric Surgery, Skåne University Hospital and the Department of Clinical Sciences, Pediatrics, Lund University, 22185 Lund, Sweden

E-mail: einar.arnbjornsson@telia.com

The authors declare no conflicts of interest.

\begin{abstract}
Purpose: The aim of this study was to identify short-term complications after video-assisted gastrostomy in children and to examine the association between complications and underlying disease.
\end{abstract}

Methods: This was a retrospective study at a single institution. Data for all children who underwent video-assisted gastrostomy during 12 years was collected. Complications occurring within three months postoperatively were analyzed.

Results: Among 421 children undergoing videoassisted gastrostomy, 402 were included in the study. The median age at surgery was two years (range one month-14 years). The most common underlying disorder was neurological disease (49\%). There were two major postoperative complications and $78 \%$ had minor complications. Minor complications included granulation tissue $(43 \%)$, leakage $(16 \%)$, wound infection (14\%), vomiting, dislodgement and pain. There was no significant difference in frequency of the various complications when compared between the underlying diseases $(\mathrm{p}=0.10-0.82)$. Wound infection was registered in overall $14 \%$ and occurred least frequently in children with neurologic disease and syndromes (10\% and $9 \%$ respectively).

Conclusion: Serious complications after videoassisted gastrostomy are rare, while minor complications occur in $78 \%$ of the children. There is no association between the frequency of complications and underlying disease according to this study.

Key words: Gastrostomy; laparoscopy; children; outcome; complications. 
Medical Research Archives, Vol. 5, Issue 6, June 2017

Complications according to underlying disease in children undergoing video-assisted gastrostomy

\section{Introduction}

Various technical options have been described for gastrostomy tube placement, including the time honored Stamm procedure, percutaneous endoscopic gastrostomy (PEG), percutaneous fluoroscopy-guided gastrostomy, several types of laparoscope-assisted gastrostomy, video-assisted gastrostomy, and a combined laparoscopic and endoscopic approach ${ }^{1}$. Consensus is lacking as to which procedure, if any, is superior.

Increasing evidence has suggested a lower rate of serious complications following video-assisted gastrostomy in comparison to PEG, open gastrostomy, or other techniques ${ }^{1,2}$. The advantages of video-assisted gastrostomy are placement of the gastrostomy under direct visualization and the performance of the gastropexy ${ }^{1-6}$. Complication rates associated with laparoscopic- or video-assisted or fully laparoscopic techniques have been reported to be inferior to those associated with other techniques ${ }^{7-11}$. However, previous studies examining postoperative complications in children undergoing video-assisted gastrostomy have included only small numbers of patients and have had various durations of follow-up ${ }^{12-20}$.

The primary aim of this study was to report the short-term complication rates after video-assisted gastrostomy in children. The secondary aim was to search for correlation between complications and underlying disease. The information on short-term outcomes after video-assisted gastrostomy, will aid in surgical planning and in the preoperative education of parents. The data are useful as a benchmark for future clinical work and for estimating the additional healthcare burden following video-assisted gastrostomy.

Copyright 2017 KEI Journals. All Rights Reserved

\section{Methods}

\subsection{Setting and patients}

All of the enrolled children underwent surgery at a tertiary pediatric surgery center that serves the South of Sweden with two million residents.

\subsection{Study design}

This was a retrospective analysis of prospectively collected data from a single institution. All children $<15$ years of age who underwent video-assisted gastrostomy from January 12005 until September 30 2016, were enrolled. Exclusion criteria were closure of the gastrostomy, open surgical gastrostomy, conversion from video-assisted gastrostomy to open gastrostomy, relocation of the gastrostomy, death or migration out of the study area. The duration of postoperative follow-up was three months.

\subsection{Data collection and follow-up}

The patients' records were reviewed and data on patient age and gender, death, whether the gastrostomy button was removed, whether a gastroraphy was required and postoperative complications developing during the first three months of follow-up were collected.

The follow-up of the children was administered by one registered nurse. Scheduled contacts, and contacts when needed, with the children's guardians, at the department and through telephone, were prospectively documented in the children's files.

\subsection{Operative technique}

Video-assisted gastrostomy entailed the laparoscope-assisted placement of a Mic-Key ${ }^{\circledR}$ gastrostomy button provided by Halyard Health, Inc. USA 12. Antibiotic prophylaxis (Trimethoprim sulpha) was 
administered routinely as one-dose preoperatively. An infra-umbilical mini laparotomy was performed. A $3-5 \mathrm{~mm}$ trocar $\left(\right.$ VersaStep $\left.{ }^{\circledR}\right)$ was then carefully advanced into the abdomen and pneumoperitoneum was established with $\mathrm{CO}_{2}$ insufflation. A $3-5 \mathrm{~mm} 30$-degree laparoscope was inserted, and the stomach was identified. A skin incision was made between the left costal margin and the umbilicus for the gastrostomy and a $5 \mathrm{~mm}$ trocar was inserted at this point, through the rectus muscle and into the abdominal cavity under laparoscopic visualization. The anterior stomach wall was grasped through this port with an instrument, with clear margins from the pylorus, and exteriorized when the grasper and trocar were pulled back. The stomach was then sutured to the rectus muscle fascia with a continuous double $\mathrm{U}$ stitch, forming a purse string suture around the gastrostomy opening in the stomach wall, and the gastrostomy tube was placed into the stomach cavity through a small incision in the stomach wall (Figure 1). Placement of the gastrostomy tube was confirmed by gastroscopy at the end of the surgical procedure.

\subsection{Complications}

Complications were generally
classified as major or minor 21 . Major complications were to include pneumoperitoneum, hemorrhage, duodenal hematoma, colon injuries, liver injuries, small bowel injuries, gastric perforation, gastrocolic fistula, peritonitis and buried bumper syndrome ${ }^{22}$. Minor complications, in line with previous studies were to include granuloma, infection requiring antibiotic treatment, leakage, vomiting, pain and dislocation of the button ${ }^{12-20}$.

\subsection{Statistical analysis}

All calculations were performed by a statistician. SPSS and SAS statistical software was used. Fisher's exact test and chi-squared test was used to evaluate the null hypothesis. A p-value $<0.05$ was considered statistically significant.

\subsection{Ethical considerations}

The study procedures were followed in accordance with the revised Helsinki Declaration of 1964 and the Good Clinical Practice (GCP) guidelines. The study was approved by the Regional Ethical Review Board (registration numbers 2010/49 and 2014/219. The data were coded and de-identified. The included children were registered according to the regional demands on quality register, number 01481271007173 .

\section{Results}

A total of 421 pediatric patients underwent video-assisted gastrostomy during the study period and were included in the three month follow-up period. Nineteen patients were excluded from the data analysis because of lacking data (9), repositioning of the gastrostomy (6), conversion to open surgery (3) and removal of the gastrostomy button before end of the follow-up period (1). No patient died during the follow-up period. 


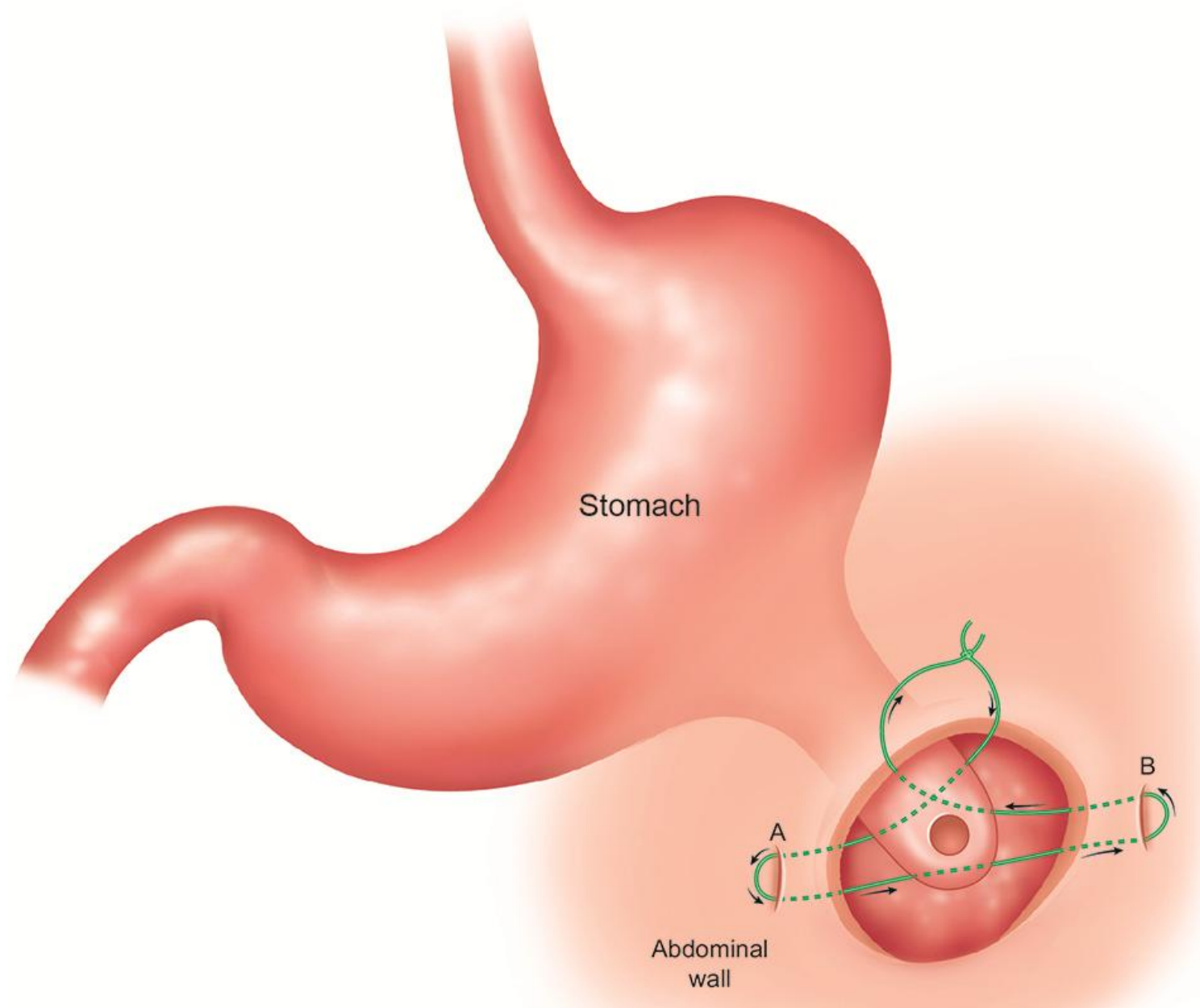

Figure 1. Video-assisted gastrostomy using a double continuous U-stitch. The U-stitch forms a purse-string suture around the gastrostomy and the stomach is attached to the abdominal wall through the skin incisions (A and B).

Finally, a total of 402 children (211 boys and 191 girls) were evaluated with regard to short-term complications. At the time of surgery, the median age was two years (range one month to 14 years). Table 1 summarizes the clinical data of the children who were included in the study.
The largest proportion of the patients $(\mathrm{n}=149 ; 49 \%)$ had an underlying neurological disease. Furthermore, 251 $(61 \%)$ of the children had more than one diagnosis. The most important diagnosis for each child to receive the gastrostomy was selected, as summarized in Figure 2. 


\section{Table 1}

Patient characteristics of 402 children undergoing video-assisted gastrostomy

\begin{tabular}{|l|c|}
\hline Number of patients & 402 \\
\hline Male/female & $211 / 191$ \\
\hline Age (median, years) (Range) & $2(0.1-14)$ \\
\hline Weight (median, kg) & $9(4-39)$ \\
\hline Z-score* for weight & $-2.0 \pm 1.7(-6.7-1.9)$ \\
\hline Length (median, cm) & $75(49-159)$ \\
\hline Z-score* for length & $-2.0 \pm 1.8(-7.0-1.7)$ \\
\hline
\end{tabular}

The numbers are presented as median (min-max), or as mean \pm SD (min-max).

* Z-scores are calculated as (actual weight - mean weight) / standard deviation according to the national standardized weight curves.

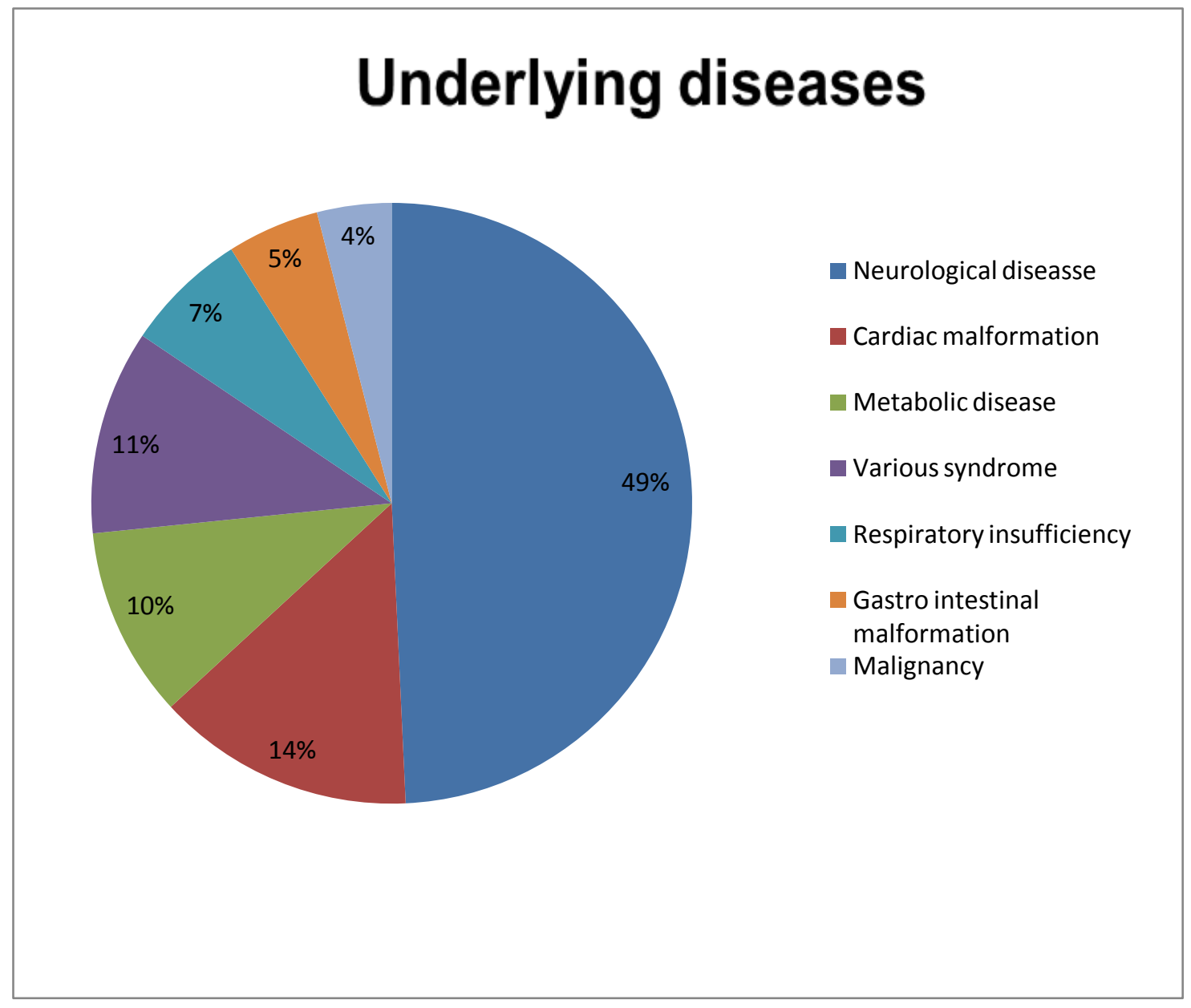

Figure 2. Underlying diagnoses in 402 children undergoing a video-assisted gastrostomy 
Since there were no differences in outcomes between boys and girls, the results are presented gender-mixed. Short-term minor complications are summarized in Table 2 and Figure 3. The only noted major complications were one broken thread at the knot, and one placement of the gastrostomy too close to the pylorus, both leading to reoperation.

There was no correlation between the underlying diagnoses and the frequency of complications, Table 2.

Table 2

Correlation between underlying diagnosis and postoperative complications during the first 3 months after video-assisted gastrostomy

\begin{tabular}{|c|c|c|c|c|c|c|c|c|c|}
\hline Complication & n $(\%)$ & 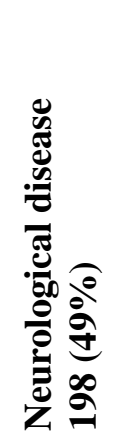 & 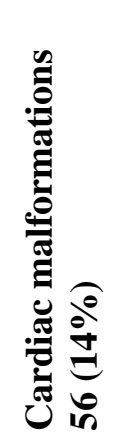 & 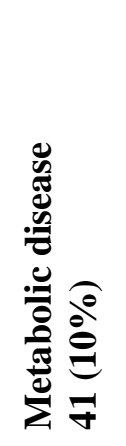 & 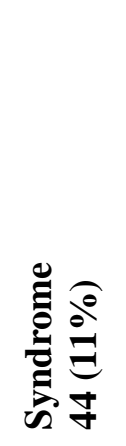 & 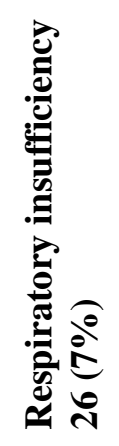 & 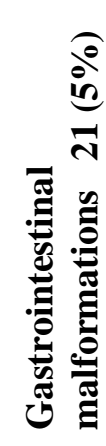 & 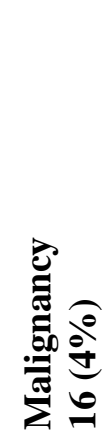 & P-value* \\
\hline Granulation tissue & $173(43)$ & $97(49)$ & $24(43)$ & $16(39)$ & $11(25)$ & $17(65)$ & $2(10)$ & $6(38)$ & 0.44 \\
\hline Leakage & $64(16)$ & $34(17)$ & $11(20)$ & $4(10)$ & $8(18)$ & $5(19)$ & $0(0)$ & $2(13)$ & 0.82 \\
\hline Wound infection & $56(14)$ & $19(10)$ & $14(25)$ & $7(17)$ & $4(9)$ & $6(23)$ & $1(5)$ & $5(31)$ & 0.10 \\
\hline Tube dislodgement & $20(5)$ & $11(6)$ & $1(2)$ & $2(5)$ & $5(11)$ & $1(4)$ & $0(0)$ & $0(0)$ & 0.21 \\
\hline Vomiting & $72(18)$ & $33(17)$ & $11(20)$ & $6(15)$ & $9(20)$ & $5(19)$ & $2(10)$ & $6(38)$ & 0.63 \\
\hline Pain & $8(2)$ & $0(0)$ & $1(2)$ & $3(7)$ & $1(2)$ & $2(8)$ & $0(0)$ & $1(6)$ & 0.65 \\
\hline Total & 393 & 233 & 78 & 49 & 47 & 40 & 10 & 20 & \\
\hline No complication & $84(21)$ & $43(22)$ & $9(16)$ & $14(34)$ & $9(20)$ & $3(12)$ & $6(29)$ & $0(0)$ & \\
\hline
\end{tabular}

*Statistical method: Chi-Square tests 


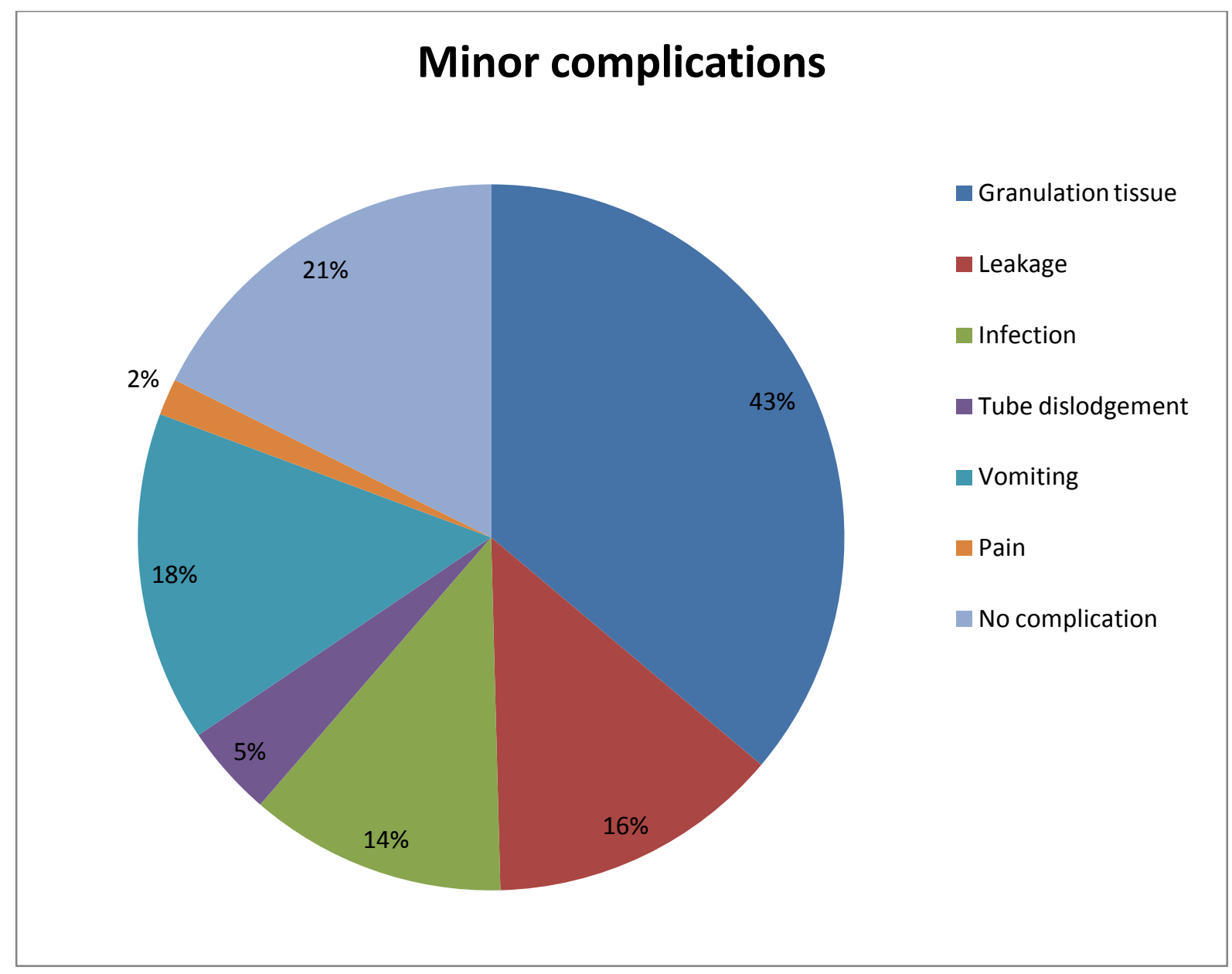

Figure 3. Complication rates during the 3-month short-term follow-up period after video-assisted gastrostomy. The figure shows the percentage of patients with each complication; a single patient may have more than one complication.

\section{Discussion}

Our study documented the frequencies of various short-term postoperative complications of video-assisted gastrostomy in a large cohort of children. The rates of infection, leakage, granulation tissue, and vomiting were high during the short-term follow-up period of three months. The high frequency of complications reported is probably due to the quality of the data collection on these complications. These complications have been shown to diminish significantly over time whereas pain and dislodgement of the gastrostomy device does not ${ }^{23}$.
The high frequency of complications may also be due to the children's underlying diseases as well as the technique used for the operative intervention. However, there was no correlation between underlying conditions and complication rates and the method used for the operative intervention was standardized.

A granuloma at the gastrostomy site was the most frequent complication in the group of children with respiratory insufficiency although not more common than in children with other diagnoses, Table 2. This may be due to low oxygen saturation in the tissue among these children. 
Also, forced respiratory movements of the abdominal wall may cause the gastrostomy button to move against the gastrostomy, and thereby facilitate the development of a granuloma.

A number of major complications have been associated with PEG. On the contrary, only a few major complications, including gastric perforation, gastrostomy dislodgment, and conversion to open procedure have been described in association with video-assisted gastrostomy. Minor complications, on the other hand, are equally encountered in both PEG and video-assisted gastrostomy ${ }^{24}$.

In this study, we selected a short-term postoperative follow-up period of three months postoperatively rather than the conventional 30 days. The reason for this is the knowledge that the most common postoperative complication, granuloma, is often not obvious at 30 days.

Other complications, such as buried bumper syndrome, were not encountered during the study period. Buried bumper syndrome, in which the internal fixation device migrates alongside the tract of the stoma outside the stomach, is known to be a severe complication to PEG placement ${ }^{25}$.

The strength of this study is that all of the patients underwent a standardized procedure that was performed by the same team of surgeons ${ }^{12}$. Furthermore, there was a large number of patients. All of the included patients were treated and followed at one institution or at institutions sharing the same set of electronic medical records. The residents of the catchment area of the study receive free health care at the time of need. Therefore, it was unlikely that any patient would drop out of treatment or follow-up due to socioeconomic factors, and there is no reason to suspect any substantial lack of information on complications in the study cohort.

The study limitations include subjective reporting and observations and individual interpretation. The patients were followed prospectively but the data for the study were retrospectively compiled from the patients' records. Complication rates might have been impacted because different treating physicians might have had different interpretations and methods of documenting their findings. Notations on the charts were made without any knowledge that the information would be collected for a retrospective study and therefore might have been not focused on the gastrostomy device. In addition, complications such as intermittent infections and leakage over an extended time period might not have been noted in the charts and therefore would not have been included in the evaluations.

The results of the study will mainly serve as a reference for physicians and other healthcare workers that can be used when informing children and their guardians on the frequency of complications and the various outcomes after video-assisted gastrostomy placement. The data should also be useful for estimating the additional inhospital and outpatient healthcare burden following video-assisted gastrostomy. The results are a benchmark for further clinical work and a foundation for discussion about improving outcomes for children undergoing gastrostomy. The question that arises is how we can use the information for improving the children's outcome by changing details in the method of operation, modification of the follow-up, more frequent controls or the type of dressing and medications used. Future prospective studies that provide more accurate results and are less prone to bias are warranted. 


\section{Conclusion}

There was no correlation between underlying conditions and complication rates after a video-assisted gastrostomy operation. These findings can provide important information for parents preoperatively and for clinical follow-up postoperatively. The most important question which we are not able to answer based on the results of this study is how the complications can be avoided. Considering all the arguments, we suggest that video-assisted gastrostomy, and particularly the U-stitch technique, should be considered the preferred technique for gastrostomy placement in pediatric patients.

Acknowledgements to BioMed Proofreading LLC for the edited manuscript, and to Elsevier Web Shop for the illustration, and to Håkan Lövkvist, biostatistician at the Competence Centre for Clinical Research, Skåne University Hospital, Lund, Sweden, for statistical advice. 


\section{References}

1. Merli L, De Marco EA, Fedele C, Mason EJ, Taddei A, Paradiso FV, Catania VD, Nanni L. Gastrostomy Placement in Children: Percutaneous Endoscopic Gastrostomy or Laparoscopic Gastrostomy? Surg Laparosc Endosc Percutan Tech. 2016 Oct;26(5):381-384. PubMed PMID: 27661204; PubMed Central PMCID: PMC5054954.

https://doi.org/10.1097/SLE.000000000 0000310

PMid:27661204 PMCid:PMC5054954

2. Lantz M, Hultin Larsson $\mathrm{H}$, Arnbjörnsson E. Literature review comparing laparoscopic and percutaneous endoscopic gastrostomies in a pediatric population. Int $\mathbf{J}$ Pediatr. 2010:507616. doi: 10.1155/2010/ 507616. Epub 2010 Mar 10. PubMed PMID: 20300186 https://doi.org/ $\underline{10.1155 / 2010 / 507616}$

3. Shimizu Y, Okuyama H, Sasaki T, Nose S, Saka R. Laparoscopic-assisted percutaneous endoscopic gastrostomy: a simple and efficient technique for disabled elderly patients. J Parenter Enteral Nutr. 2014;38:475-480. https://doi.org/10.1177/0148607113481 476 PMid:23520134

4. Yu SC, Petty JK, Bensard DD, Partrick DA, Bruny JL, Hendrickson RJ. Laparoscopic-assisted percutaneous endoscopic gastrostomy in children and adolescents. JSLS. 2005 JulSep;9(3):302-4. PMCID: PMC3015611 PMID: 16121876 [Indexed for MEDLINE]

5. Idowu O, Driggs XA, Kim S. Laparoscopically assisted antegrade percutaneous endoscopic gastrostomy. J
Pediatr Surg. 2010;45:277-279. https://doi.org/10.1016/j.jpedsurg.2009. 08.017 PMid:20105621

6. Given MF, Hanson JJ, Lee MJ. Interventional radiology techniques for provision of enteral feeding. Cardiovasc Intervent Radiol. 2005;28:692-703. https://doi.org/10.1007/s00270-0047021-7 PMid:16184329

7. Akay B, Capizzani TR, Lee AM, Drongowski RA, Geiger JD, Hirschl RB, Mychaliska GB. Gastrostomy tube placement in infants and children: is there a preferred technique? J Pediatr Surg. 2010;45:1147-1152. https://doi.org/10.1016/j.jpedsurg.2010. 02.079 PMid:20620310

8. Jones VS, La Hei ER, Shun A. Laparoscopic gastrostomy: the preferred method of gastrostomy in children. Pediatr Surg Int. 2007;23:1085-1089. https://doi.org/10.1007/s00383-0072015-6 PMid:17828404

9. Vervloessem D, van Leersum F, Boer D, Hop WC, Escher JC, Madern GC, de Ridder L, Bax KN. Percutaneous endoscopic gastrostomy (PEG) in children is not a minor procedure: risk factors for major complications. Semin Pediatr Surg. 2009;18:93-97. https://doi.org/10.1053/j.sempedsurg.20 09.02.006 PMid:19348998

10. Zamakhshary M, Jamal M, Blair GK, Murphy JJ, Webber EM, Skarsgard ED. Laparoscopic vs percutaneous endoscopic gastrostomy tube insertion: a new pediatric gold standard? J Pediatr Surg. 2005;40:859-862. https://doi.org/10.1016/j.jpedsurg.2005. 02.001 PMid:15937831 
11. Liu R, Jiwane A, Varjavandi A, Kennedy A, Henry G, Dilley A, Currie B, Adams S, Krishnan U. Comparison of percutaneous endoscopic, laparoscopic and open gastrostomy insertion in children. Pediatr Surg Int. 2013;29:613-621. https://doi.org/10.1007/s00383-0133313-9 PMid:23632756

12. Backman T, Sjövie H, Kullendorff CM, Arnbjörnsson E. Continuous double Ustitch gastrostomy in children. Eur J Pediatr Surg. 2010; 20:14-17 https://doi.org/10.1055/s-0029-1238316 PMid:19830661

13. Mikaelsson C, Arnbjörnsson E. Singlepuncture laparoscopic gastrostomy in children. Pediatr Surg Int. 1998;14:4344.

https://doi.org/10.1007/s003830050432 PMid:9880694

14. Arnbjörnsson E, Larsson LT, Lindhagen T. Complications of laparoscopy-aided gastrostomies in pediatric practice. J Pediatr Surg. 1999; 34:1843-1846 https://doi.org/10.1016/S0022$\underline{3468(99) 90327-5}$

15. Andersson L, Mikaelsson C, Arnbjörnsson E, Larsson LT. Laparoscopy aided gastrostomy in children. Ann Chir Gynaecol. 1997; 86:19-22.

PMid:9181214

16. Norén E, Gunnarsdóttir A, Hanséus K, Arnbjörnsson E. Laparoscopic gastrostomy in children with congenital heart disease. J Laparoendosc Adv Surg Tech A. 2007; 17:483-489. https://doi.org/10.1089/lap.2006.0119

PMid:17705732
17. Backman T, Berglund $Y$, Sjövie $H$, Arnbjörnsson E. Complications of video-assisted gastrostomy in children with or without a ventriculoperitoneal shunt. Pediatr Surg Int. 2007; 23:665668 https://doi.org/10.1007/s00383007-1930-x

PMid:17487495

18. Plantin I, Arnbjörnsson E, Larsson LT. No increase in gastroesophageal reflux after laparoscopic gastrostomy in children. Pediatr Surg Int. 2006; 22:581584

https://doi.org/10.1007/s00383-0061707-7 PMid:16807719

19. Arnbjörnsson E, Backman T, Mörse H, Berglund Y, Kullendorff CM, Lövkvist H. Complications of video-assisted gastrostomy in children with malignancies or neurological diseases. Acta Paediatr. 2006; 95:467-470 https://doi.org/10.1080/0803525050043 7515

https://doi.org/10.1111/j.16512227.2006.tb02263.x PMid:16720496

20. Backman T, Arnbjörnsson E, Berglund Y, Larsson LT. Video-assisted gastrostomy in infants less than 1 year. Pediatr Surg Int. 2006; 22:243-246. https://doi.org/10.1007/s00383-0051628-X PMid:16402265

21. Schrag SP, Sharma R, Jaik NP, Seamon MJ, Lukaszczyk JJ, Martin ND, Hoey BA, Stawicki SP. Complications related to percutaneous endoscopic gastrostomy (PEG) tubes. A comprehensive clinical review. J Gastrointest Liver Dis. 2007;16:407-418.

PMid:18193123

22. Khalil Q, Kibria R, Akram S. Acute buried bumper syndrome. South Med J. 2010;103:1256-1258. 
Medical Research Archives, Vol. 5, Issue 6, June 2017

Complications according to underlying disease in children undergoing video-assisted gastrostomy

https://doi.org/10.1097/SMJ.0b013e318

$1 \mathrm{fa} 73 \mathrm{~d} 0$

PMid:21037520

23. Salö M, Santimano A, Helmroth S, Stenström P, Arnbjornsson EÓ. Longterm outcomes of children undergoing video-assisted gastrostomy. Pediatr Surg Int. 2016 Nov 2. [Epub ahead of print] PubMed PMID: 27807610.

24. Wragg RC, Salminen H, Pachl M, Singh M, Lander A, Jester I, Parikh D, Jawaheer G. Gastrostomy insertion in the 21st century: PEG or laparoscopic? Report from a large single-centre series. Pediatr Surg Int. 2012;28:443-448. https://doi.org/10.1007/s00383-0123079-5 PMid:22476714

25. Cyrany J, Rejchrt S, Kopacova M, Bures J. Buried bumper syndrome: A complication of percutaneous endoscopic gastrostomy. World J Gastroenterol. 2016; 22:618-627 . https://doi.org/10.3748/wjg.v22.i2.618 PMid:26811611 PMCid:PMC4716063 